\title{
INVESTIGASI KEMAMPUAN NUMERASI MAHASISWA CALON GURU MATEMATIKA
}

\author{
Hasan Basri ${ }^{1}$ *Bambang Kurnadi², Syarifuddin³ ${ }^{3}$ Chairul Fajar Tafriliyanto4, Purna Bayu \\ Nugroho 5 \\ Universitas Madura ${ }^{1,2,4}$, STKIP Bima ${ }^{3}$, Universitas Muhammadiyah Kotabumi ${ }^{5}$ \\ Email: hasan basri@unira.ac.id¹, kurnadi@unira.ac.id², \\ syarifuddin.stkipbima@gmail.com³ ${ }^{3}$,chairul_math@unira.ac.id ${ }^{4}$, \\ purnabayupvz@gmail.com ${ }^{5}$
}

\begin{abstract}
Abstrak. Mahasiswa calon guru matematika dituntut untuk memiliki kemampuan numerasi yang baik karena kemampuan ini dibutuhkan dalam semua aspek kehidupan, baik di rumah, pekerjaan maupun masyarakat. Namun demikian kajian atau penelitian terkait kemampuan numerasi guru masih kurang. Penelitian ini bertujuan untuk mendeskripsikan kemampuan numerasi mahasiswa calon guru matematika. Subjek penelitian ini yaitu mahasiswa prodi pendidikan matematika Universitas Madura dan Universitas Muhammadiyah Kotabumi. Instrumen pada penelitian ini merupakan instrumen tes yang dibuat dalam bentuk google form terkait data sebaran covid-19. Hasil penelitian menunjukkan bahwa mahasiswa calon guru belum memiliki kemampuan numerasi yang baik hal ini didukung oleh hasil temuan bahwa belum ada satupun calon mahasiswa yang mampu menunjukkan bahwa data yang diberikan merupakan data yang tidak valid. Mahasiswa calon guru belum mampu menunjukkan validitas suatu data dengan baik, hal ini disebabkan oleh kurangnya numerasi yang dimiliki oleh calon guru matematika.
\end{abstract}

\section{Kata kunci: Investigasi, Numerasi, Mahasiswa Calon Guru}

\begin{abstract}
Prospective mathematics teacher students are required to have good numeracy skills because this ability is needed in all aspects of life, both at home, at work and in society. However, studies or research related to teacher numeracy skills are still lacking. This study aims to describe the numeracy skills of prospective mathematics teacher students. The subjects of this research are students of mathematics education study program at Madura University and Kotabumi University. The instrument in this study was made in the form of a google form related to the data on the distribution of COVID-19. The results of the study indicate that student teacher candidates do not yet have good numeracy skills. This is supported by the findings that none of the prospective students has been able to show that the data provided is invalid data.
\end{abstract}

\section{Keywords: Investigation, Numerical, Student Prospective Mathematics Teacher}

\section{A. Pendahuluan}

Numerasi sebagai salah satu literasi yang erat kaitannya dengan kehidupan sehari-hari, numerasi merupakan pengetahuan dan kecakapan (a) menggunakan berbagai macam angka dan simbol-simbol yang terkait dengan matematika dasar untuk memecahkan masalah praktis dalam berbagai konteks kehidupan sehari-hari (b) menganalisis informasi yang ditampilkan dalam berbagai bentuk (grafik, tabel, bagan, dan sebagainya) (c) menggunakan interpretasi tersebut untuk mempredikasi dan mengambil keputusan (Dantes \& Handayani, 2021). Sedangkan Ekowati, dkk (2019) menyatakan bahwa numerasi adalah kemampuan seseorang untuk merumuskan, menerapkan, dan menafsirkan matematika berbagai konteks, termasuk kemampuan melakukan penalaran secara matematis, menggunakan konsep, prosedur dan fakta untuk menggambarkan, menjelaskan atau memperkirakan fenomena/kejadian.

Literasi numerasi terdiri dari tiga aspek berupa berhitung, relasi numerasi, dan operasi aritmatik. Berhitung adalah kemampuan untuk menghitung suatu benda secara verbal dan kemampuan untuk mengidentifikasi jumlah dari benda. Relasi numerasi berkaitan dengan kemampuan untuk membedakan kuantitas suatu benda seperti lebih banyak, lebih sedikit, lebih tinggi, atau lebih pendek. Sementara itu, operasi aritmatika adalah kemampuan untuk 
mengerjakan operasi matematika dasar berupa penjumlahan dan pengurangan. Tiga aspek literasi numerasi yang telah dijelaskan sebelumnya merupakan aspek dasar dalam pembelajaran matematika yang penting diperkenalkan sejak usia dini hingga anak memasuki kelas rendah (Mahmud, dkk., 2019)

Numerasi merupakan salah satu keterampilan yang ditetapkan oleh UNESCO pada tahun 2006 sebagai salah satu penentu kemajuan bangsa (Kemendikbud, 2017). Ketika kita mampu menguasai numerasi dengan baik, maka kita akan memiliki kepekaan terhadap numerasi itu sendiri. Ketika kita mampu menerapkan kepekaan tersebut, tentunya kita akan mampu untuk mengelola sumber daya alam yang kita miliki dan SDM kita akan mampu bersaing dengan negara-negara lain sehingga kita akan menjadi bangsa yang kuat. Dengan kata lain peningkatan kemampuan numerasi berbanding lurus dengan kemajuan suatu bangsa, oleh karenanya perlu usaha untuk meningkatkan kemampuan numerasi.

Mengingat pentingnya numerasi bagi keberlangsungan hidup dan kemajuan suatu bangsa nantinya, maka peserta didik perlu dibekali untuk memiliki kepekaan terhadap numerasi. Hal ini sejalan dengan program pemerintah Kementerian Pendidikan dan Kebudayaan tahun 2016 yang mewacanakan Gerakan Literasi Nasional (GLN). Gerakan Literasi Nasional merupakan implementasi dari Permendikbud Nomor 23 Tahun 2015 tentang Penumbuhan Budi Pekerti. Gerakan Literasi Nasional (GLN) yang telah dicanangkan pemerintah, dilaksanakan melalui pendidikan di sekolah yang disebut dengan Gerakan Literasi Sekolah (GLS). Gerakan Literasi Sekolah dapat diartikan sebagai upaya yang dilakukan untuk mewujudkan organisasi pebelajar yang literat dan menumbuhkan budi pekerti bagi warga sekolah melalui berbagai aktivitas meliputi kegiatan membaca buku non pembelajaran selama 15 menit (Ekowati, dkk., 2019; Helfiana, dkk., 2020)

Namun pentingnya pengetahuan numerasi tidak berbanding lurus dengan berbagai hasil studi maupun penelitian terkait kemampuan numerasi siswa di Indonesia. hasil studi PISA menggatakan kemampuan numerasi peserta didik dindonesia masih tergolong rendah, Peserta didik Indonesia berada pada peringkat 72 dari 79 negara peserta tes. Hasil tes menunjukan bahwa rata-rata skor peserta didik adalah 371 dalam membaca, matematika 379, dan sains 396. Capaian skor tersebut di bawah rata-rata 79 negara-negara peserta PISA, yakni 487 untuk kemampuan membaca, dan 489 untuk kemampuan matematika dan sains (OECD, 2017). Selain hasil studi PISA, beberapa penelitian juga menunjukkan kemampuan literasi matematatika atau numerasi siswa masih rendah (Rahmawati, 2014; Rusmining \& Sugianto, 2014; Santia, 2018).

Wardhani \& Rumiati (2011) yang mengungkapkan bahwa salah satu faktor yang menjadi penyebab rendahnya kemampuan literasi matematika di tingkat internasional adalah siswa Indonesia yang tidak terbiasa memecahkan soal-soal matematika berkarakteristik seperti soalsoal TIMSS (Trends International Mathematics and Science Study) dan PISA. Hal ini tentunya didukung oleh iklim belajar di sekolah guru belum maksimal dalam memberikan pembiasaan terhadap siswa dalam menyelesaikan permasalahan yang menuntut berpikir tingkat tinggi (Hadi \& Novaliyosi, 2019). Selama ini penelitian yang dilakukan terkait numerasi banyak yang berfokus pada siswa, sangat jarang penelitian terkait numerasi yang berkaitan dengan guru atau calon guru matematika. Guru tentunya sebagai fasilitator yang baik bagi siswa, harus memiliki kemampuan numerasi yang baik. Kemampuan literasi dan numerasi merupakan dasar dari keterampilan berpikir atau bernalar tinggi (Higher Order Thinking Skills/HOTS), seperti berpikir kritis dan mampu memecahkan masalah (Kemdikbud \& Goverment, 2019). Hal ini lah yang mendasari kami untuk melakukan penelitian terkait investigasi kemampuan numerasi mahasiswa calon guru matematika.

\section{B. Metode Penelitian}

Metode penelitian yang digunakan dalam penelitian ini adalah penelitian deskriptif dengan pendekatan kualitatif. Prosedur penelitian ini terdiri dari 3 tahapan utama yaitu 
persiapan, implementasi, dan analisis data. Pada tahap persiapan peneliti membuat google form (GF) yang berisi pertanyaan terkait validitas dari data yang diberikan. Pada tahap implementasi, peneliti menyebarkan GF kepada subjek penelitian, dilanjutkan dengan tahap ketiga yaitu menganalisis jawaban mahasiswa untuk mengetahui dan mengidentifikasi kemampuan numerasi calon guru matematika. Pada data yang diberikan sengaja diselipkan data yang tidak valid, untuk melihat kepekaan subjek terhadap numerasi data. Penelitian ini melibatkan mahasiswa pendidikan matematika di Universitas Madura dan Universitas Muhammadiyah Kotabumi. Subjek penelitian ini adalah 126 mahasiswa semester IV-VIII yang terdiri atas 99 perempuan dan 31 laki-laki. Pemilihan subjek berdasarkan pertimbangan bahwa mahasiswa pada semester tersebut telah menempuh beberapa matakuliah matematika, sehingga telah memiliki pola pikir yang matematis.

\section{Hasil Penelitian dan Pembahasan}

Penelitian ini bertujuan untuk mengidentifikasi kemampuan numerasi calon guru matematika, dengan cara memberikan mahasiswa permasalahan terkini terkait jumlah orang yang positif, sembuh dan meninggal akibat covid-19, mengenai kevalidan sebaran data covid19 yang secara jelas ditunjukkan pada gambar 1.

\begin{tabular}{|c|c|c|c|}
\hline Kabupaten/ & & mlah Orar & \\
\hline Kota & Positif & Sembuh & Meninggal \\
\hline A & 3832 & 1188 & 317 \\
\hline B & 912 & 123 & 79 \\
\hline $\mathrm{C}$ & 280 & 47 & 27 \\
\hline $\mathrm{D}$ & 184 & 118 & 70 \\
\hline $\mathrm{E}$ & 160 & 62 & 22 \\
\hline $\mathrm{F}$ & 146 & 12 & 42 \\
\hline $\mathrm{G}$ & 126 & 15 & 11 \\
\hline $\mathrm{H}$ & 120 & 110 & 10 \\
\hline I & 117 & 43 & 18 \\
\hline $\mathrm{J}$ & 109 & 19 & 12 \\
\hline $\mathrm{K}$ & 88 & 63 & 26 \\
\hline $\mathrm{L}$ & 86 & 36 & 5 \\
\hline M & 83 & 8 & 5 \\
\hline $\mathrm{N}$ & 82 & 16 & 18 \\
\hline $\mathrm{O}$ & 78 & 18 & 14 \\
\hline
\end{tabular}

\section{Gambar 1 Data pada instrumen Tes}

Sebanyak 40 mahasiswa calon guru matematika menjawab bahwa data yang diberikan adalah valid. Mereka belum mampu menemukan adanya data yang tidak valid pada sebaran data yang diberikan pada soal. Pada tabel 1, disajikan beberapa alasan yang disebutkan oleh responden dalam Google Form. 
Tabel 1. Alasan Jawaban "Valid"

\begin{tabular}{|c|c|c|}
\hline Jawaban & $\begin{array}{c}\text { Identitas } \\
\text { Responden }\end{array}$ & Alasan \\
\hline \multirow{9}{*}{ Valid } & $\mathrm{R} 1$ & $\begin{array}{l}\text { Karena dikeluarkan oleh pemerintah setempat. Sehingga } \\
\text { bisa dijadikan dasar untuk menetapkan suatu kebijakan }\end{array}$ \\
\hline & R9 & $\begin{array}{l}\text { Karena sebuah data pastinya sudah di konfirmasi } \\
\text { sebelumnya kan }\end{array}$ \\
\hline & $\mathrm{R} 15$ & $\begin{array}{l}\text { Karena data tersebut sudah memuat orang-orang yang } \\
\text { positif Corona, orang-orang yang sembuh dan juga orang- } \\
\text { orang yang sudah meninggal }\end{array}$ \\
\hline & R17 & $\begin{array}{l}\text { Karena positif, sembuh dan meninggal itu setiap kota } \\
\text { berbeda }\end{array}$ \\
\hline & R44 & $\begin{array}{l}\text { Karena jumlah orang yang sembuh dan meninggal kurang } \\
\text { dari jumlah orang yang positif. Terkadang terdapat data } \\
\text { yang menyatakan bahwa jumlah orang yang meninggal dan } \\
\text { sembuh lebih banyak dari jumlah orang yang positif }\end{array}$ \\
\hline & R62 & $\begin{array}{l}\text { Karena data tersebut belum tentu spesifik kabupaten/kota yg } \\
\text { terdampak covid } 19 \text {. }\end{array}$ \\
\hline & R77 & $\begin{array}{l}\text { Karena jelas ada kabupaten, kemudian pasien positif, } \\
\text { sembuh dan meninggal. }\end{array}$ \\
\hline & R79 & $\begin{array}{l}\text { Karena jika tidak valid maka kebijakan akan berubah-ubah } \\
\text { dan tidak konsisten }\end{array}$ \\
\hline & R84 & $\begin{array}{l}\text { Karena sebelumnya pasti ada perhitungan dari rumah sakit } \\
\text { di daerah-dareha yang mennangani covid19 jadi data } \\
\text { tersebut dapat dijadikambpenetapan suatu kebijakan seperti } \\
\text { jika pesebarannnya banyak makan di adakannya lockdown, } \\
\text { PSBB dan jaga jarak }\end{array}$ \\
\hline
\end{tabular}

Berdasarkan tabel 1, terlihat beberapa alasan yang disampaikan oleh mahasiswa calon guru dalam menguatkan jawaban yang diberikan. Namun demikian banyak alasan yang dibuat tidak berdasarkan data yang diberikan pada soal, misalnya alasan R1, R9, R79 dan R84. Berbeda dengan alasan keempat responden sebelumnya alasan yang diberikan oleh R15, R17, R62 dan R77 didasarkan pada data yang ada pada soal, namun demikian alasan yang dibuat masih belum logis misalnya "karena jelas ada kabupaten, kemudian pasien positif, sembuh dan meninggal" hal ini menunjukkan bahwa responden tidak memiliki kemampuan numerasi yang baik karena belum mampu melakukan analisis terhadap informasi yang diberikan dengan baik sehingga salah dalam memberikan penafsiran terhadap data yang diberikan (Hartatik, 2020). Sedangkan satu responden yaitu R44 menjawab valid namun memberikan alasan yang saling kontradiksi, yang maan ada satu atau lebih pernyataan yang bertentangan (Hernadi, 2013; Purwanto, 2012).

Sebanyak 43 mahasiswa calon guru matematika menjawab bahwa data yang diberikan adalah tidak valid. Namun demikian tidak semuanya mahasiswa calon guru mampu menemukan fakta terkait kegagalan data tersebut untuk menjadi data yang valid, hanya ada satu responden/mahasiswa calon guru matematika yang dapat menemukan data yang tidak valid yang diberikan pada soal tersebut. Pada tabel 2, disajikan beberapa alasan yang disebutkan oleh responden dalam GF. 
Tabel 2. Alasan Jawaban Tidak Valid

\begin{tabular}{|c|c|c|}
\hline Jawaban & $\begin{array}{c}\text { Identitas } \\
\text { Responden } \\
\end{array}$ & Alasan \\
\hline \multirow{10}{*}{ Tidak Valid } & $\mathrm{R} 2$ & Tidak ada \\
\hline & R3 & $\begin{array}{l}\text { Karena pada kenyataannya contoh saya di kota } \\
\text { surabaya, semakin banyak pasien positif maka } \\
\text { semakin banyak pula pasien yang meninggal }\end{array}$ \\
\hline & R10 & $\begin{array}{l}\text { Karena hanya menyebutkan kota dengan inisial huruf } \\
\text { saja, jika memang hanya sebagai contoh soal maka } \\
\text { dapat dikatakan valid dengan pertimbangan. }\end{array}$ \\
\hline & R11 & $\begin{array}{l}\text { Data tersebut tidak diketahui asal usulnya (siapa yang } \\
\text { mendatanya, misal pemerintah atau lembaga tertentu). }\end{array}$ \\
\hline & R13 & $\begin{array}{l}\text { Data tersebut kurang valid karena data diatas kurang } \\
\text { lengkap seperti data jumlah orang positif yang } \\
\text { dirawat, PDP dan ODP tidak tertera. }\end{array}$ \\
\hline & R18 & $\begin{array}{l}\text { Karena data yang valid ada informasi tentang latar } \\
\text { belakang sipenulis sedangkan data diatas tidak ada, } \\
\text { ada tanggal update tulisan tersebut sedangkan data } \\
\text { diatas juga tidak ada. }\end{array}$ \\
\hline & R35 & $\begin{array}{l}\text { Karna menggunakan sampel kota atau daerah yg tidka } \\
\text { jelas }\end{array}$ \\
\hline & R39 & $\begin{array}{l}\text { Karna dalam data tersebut hanya memaparkan pasien } \\
\text { yang positif, sembuh, dan meninggal dikarenakan } \\
\text { covid' } 19\end{array}$ \\
\hline & R57 & Karena bukan dari pemerintah yang mengeluarkan. \\
\hline & R99 & $\begin{array}{l}\text { Karena dikota } \mathrm{D} \text {, terdapat kelebihan orang yang } \\
\text { meninggal dan sembuh, psotiv }(184) \text { tidak sama } \\
\text { dengan } 118 \text { sembuh }+70 \text { meninggal }\end{array}$ \\
\hline
\end{tabular}

Berdasarkan tabel 2, terlihat beberapa alasan yang disampaikan oleh mahasiswa calon guru dalam menguatkan jawaban yang diberikan. Namun demikian masih ada calon mahasiswa yang tidak memberikan alasannya, misalnya alasan R2. Sama halnya dengan alasan pada saat menjawab valid, pada bagian ini juga ditemukan beberapa responden dalam hal ini calon guru matematika yang memberikan alasan diluar data yang diberikan pada soal misalnya R10, R11, R13, R18, R35, R39 dan R57. R3 memberikan alasan "karena pada kenyataannya contoh saya di kota surabaya, semakin banyak pasien positif maka semakin banyak pula pasien yang meninggal" merupakan kesimpulan yang diambil tidak termasuk dalam pengambilan keputusan yang valid karena hanya berlaku pada kondisi tertentu saja (Hernadi, 2013; Purwanto, 2012). Dari 43 responden/calon guru matematika yang menyatakan data tersebut tidak valid, hanya ada satu mahasiswa yang memiliki kemampuan numerasi yang sangat baik karena R99 telah mampu menganalisis dan menginterpretasikan informasi yang diberikan di soal dengan baik (Hartatik, 2020).

Sebanyak 43 mahasiswa calon guru matematika tidak menyatakan secara pasti terkait validitas dari data yang diberikan pada soal. Secara terperinci alasan responden dalam memberikan jawaban yang terekem dalam GF disajikan pada tabel 3. 
Tabel 3. Alasan Tidak Menjawab Valid atau Tidak Valid

\begin{tabular}{|c|c|c|}
\hline Jawaban & $\begin{array}{c}\text { Identitas } \\
\text { Responden }\end{array}$ & Alasan \\
\hline \multirow{12}{*}{$\begin{array}{l}\text { Tidak } \\
\text { Menjawab } \\
\text { Valid atau } \\
\text { Tidak Valid }\end{array}$} & $\mathrm{R} 4$ & Menurut pendapat saya data tersebut cukup valid. \\
\hline & & Karena dengan adanya data tersebut mempermudah \\
\hline & & menganalisis dan mencegah menyebarnya virus \\
\hline & & covid.19 tersebut secara maksimal. \\
\hline & R5 & $\begin{array}{l}\text { Saya tidak dapat memastikan data itu valid atau tidak, } \\
\text { karena nama provinsi dan kota yang tidak jelas }\end{array}$ \\
\hline & $\mathrm{R} 20$ & Kurang valid, karena belum tentu kebenarannya \\
\hline & R49 & $\begin{array}{l}\text { Akan lebih baik apabila nama kabupaten/kota di tulis } \\
\text { dengan jelas agar penanganannya lebih mudah dan } \\
\text { tepat sasaran. }\end{array}$ \\
\hline & R56 & $\begin{array}{l}\text { Belum tentu valid. Karena kabar dimasyarakat orang } \\
\text { yang tidak sakit corona tapi di coronakan ( disangka } \\
\text { positif ) }\end{array}$ \\
\hline & R66 & $\begin{array}{l}\text { Menurut saya data diatas belum tentu valid. Karena, } \\
\text { suatu data dianggap valid jika sudah divalidasi oleh } \\
\text { pemerintah dan sudah disahkan oleh tim Gugus Tugas. }\end{array}$ \\
\hline & $\mathrm{R} 85$ & $\begin{array}{l}\text { Cukup benar tanpa kekeliruan dalam perhitungan } \\
\text { jumlah sembuh dan jumlah kematian dengan jumlah } \\
\text { positif covid } 19 \text { nya }\end{array}$ \\
\hline & R109 & $\begin{array}{l}\text { Kemungkinan tidak sepenuhnya valid karena } \\
\text { kemungkinan ada yang terpapar virus ini namun tidak } \\
\text { terdata. Seperti OTG yang berpotensi menjadi } \\
\text { penyebar virus ini tanpa dia sadari }\end{array}$ \\
\hline & R114 & $\begin{array}{l}\text { Data tersebut mungkin saja bisa saja di percaya dan } \\
\text { bisa di jadikan dasar penetapan kebijakan namun } \\
\text { kembali lagi kita harus memahami bagaimana } \\
\text { cepatnya virus ini menular data di atas mungkin hanya } \\
\text { data orang } 2 \text { yang sudah di periksa mengingat yg } \\
\text { terjangkit virus ini bisa saja tidak memiliki gejala } \\
\text { sehingga kemungkinan besar kasus positif } \\
\text { kenyataannya lebih banyak dari yg tertulis di data } \\
\text { tersebut. Sehingga kebijakan yang di buat harus lebih } \\
\text { hati2. }\end{array}$ \\
\hline
\end{tabular}

Berdasarkan tabel 3, terlihat beberapa alasan yang disampaikan oleh mahasiswa calon guru dalam menguatkan jawaban yang diberikan. Beberapa kalimat yang menyatakan mereka tidak dalam menentukan valid atau tidak valid data yang diberikan sebagai berikut : "cukup valid";" tidak dapat memastikan data itu valid atau tidak";" belum tentu valid"; Cukup benar; "Kemungkinan tidak sepenuhnya valid"; "mungkin saja bisa saja di percaya". Alasan-alasan tersebut tentunya merupakan ketidakyakinan responden terhadap data yang diberikan.

Berdasarkan hasil analisis data peneliti menemukan beberapa kategori jawaban mahasiswa terhadap permasalahan yang diberikan. Seluruh kategori jawaban mahasiswa dapat dilihat pada tabel 4 . 
Tabel 4.Jawaban Mahasiswa Calon Guru

\begin{tabular}{lr}
\hline Jawaban & Jumlah \\
\hline Valid & 40 \\
Tidak Valid & 43 \\
Tidak Menjawab Valid atau Tidak & 43 \\
\hline
\end{tabular}

Berdasarkan jawaban mahasiswa calon guru di atas terlihat bahwa tidak ada yang mendominasi dari jawaban mahasiswa calon guru matematika. Bahkan masih ada 43 mahasiswa calon guru yang belum dapat menentukan kevalidan dari data yang diberikan. Total ada sebanyak 83 mahasiswa yang belum mampu menunjukkan bahwa data yang diberikan adalah data yang tidak valid. Dengan kata lain mayoritas calon guru matematika memiliki kemampuan numerasi yang rendah, hasil ini sejalan dengan penelitian yang dilakukan oleh Ayuningtyas \& Sukriyah (2020) dan Hartatik (2020).

\section{Kesimpulan dan Saran}

Mahasiswa calon guru matematika belum memiliki kemampuan numerasi yang baik hal ini didukung oleh hasil temuan bahwa belum ada satupun calon mahasiswa yang mampu menunjukkan bahwa data yang diberikan merupakan data yang tidak valid. Mahasiswa calon guru belum memiliki kepekaan terhadap angka, dan hanya sibuk memberikan alasan di luar data yang diberikan. Hasil penelitian ini diharapkan dapat dijadikan ajuan bagi lembaga pendidikan tinggu khususnya LPTK, dalam menyusun rencana matakuliah bagi mahasiswa calon guru matematika. Harapannya, calon guru matematika memiliki kemampuan numerasi yang baik dan dapat berdampak nantinya bagi peningkatan numerasi peserta didiknya.

\section{DAFTAR PUSTAKA}

Ayuningtyas, N., \& Sukriyah, D. (2020). Analisis pengetahuan numerasi mahasiswa matematika calon guru. Delta-Pi: Jurnal Matematika Dan Pendidikan Matematika, 9(2), 237-247.

Dantes, N., \& Handayani, N. N. L. (2021). Peningkatan Literasi Sekolah Dan Literasi Numerasi Melalui Model Blanded Learning Pada Siswa Kelas V Sd Kota Singaraja. 1(3), 269-283.

Ekowati, D. W., Astuti, Y. P., Utami, I. W. P., Mukhlishina, I., \& Suwandayani, B. I. (2019). Literasi Numerasi di SD Muhammadiyah. ELSE (Elementary School Education Journal) : Jurnal Pendidikan Dan Pembelajaran Sekolah Dasar, 3(1), 93. https://doi.org/10.30651/else.v3i1.2541

Hadi, S., \& Novaliyosi. (2019). TIMSS Indonesia (Trends in International Mathematics and Science Study). Prosiding Seminar Nasional \& Call For Papers Program Studi Magister Pendidikan Matematika Universitas Siliwangi, 562-569. http://jurnal.unsil.ac.id/index.php/sncp/article/view/1096

Hartatik, S. (2020). Indonesia Kemampuan Numerasi Mahasiswa Pendidikan Profesi Guru Sekolah Dasar dalam Menyelesaikan Masalah Matematika. Education and Human Development Journal, 5(1), 32-42. https://doi.org/10.33086/ehdj.v5i1.1456 
Helfiana, M., Sari, N., \& Suciani. (2020). Efektivitas Gerakan Literasi 15 Menit Dalam Menumbuhkan Minat Baca Siswa Autis Kelas IV Slb Tncc Banda Aceh Mata Pelajaran Bahasa Indonesia. BIDAYAH, 11(2), 143-158.

Hernadi, J. (2013). Metoda Pembuktian dalam Matematika. Jurnal Pendidikan Matematika, 2(1), 1-13. https://doi.org/10.22342/jpm.2.1.295.

Kemdikbud, \& Govermen, A. (2019). Numerasi Dasar: Fondasi Masa Depan Siswa. Balitbang.

Kemendikbud. (2017). Materi Pendukung Literasi Numerasi. In Kementerian Pendidikan dan Kebudayaan (Vol. 53, Issue 9).

Mahmud, M. R., Pratiwi, I. M., Islam, U., Sunan, N., Djati, G., Islam, U., Sunan, N., \& Djati, G. (2019). Literasi numerasi siswa dalam pemecahan masalah tidak terstruktur. Kalamatika Jurnal Pendidikan Matematika, 4(1), 69-88.

OECD. (2017). PISA for Development Assessment and Analytical Framework: Reading, Mathematics and Science (Preliminar). OECD Publishing.

Purwanto. (2012). Argumen Valid. Aditya Media Publishing.

Rahmawati, \& Mahdiansyah. (2014). Literasi Matematika Siswa Pendidikan Menengah: Analisis Menggunakan Desain Tes Internasional dengan Konteks IndonesiaRahmawati, and Mahdiansyah. "Literasi Matematika Siswa Pendidikan Menengah: Analisis Menggunakan Desain Tes Internasional Dengan Konteks. Jurnal Pendidikan Dan Kebudayaan, 20, 452-469.

Rusmining, Waluya, S. B., \& Sugianto. (2014). Analysis of Mathematics Literacy, Learning Constructivism and Character Education (Case Studies on XI Class of SMK Roudlotus Saidiyyah Semarang, Indonesia). International Journal of Education and Research., 2, 331-340.

Santia, I. (2018). Analisis Kemampuan Literasi Matematis Siswa Smp Berdasarkan Motivasi Belajar Siswa. JIPMat, 3(2), 81-85. https://doi.org/10.26877/jipmat.v3i2.2748

Wardhani, S., \& Rumiati. (2011). Instrumen Penilaian Hasil Belajar Matematika SMP: Belajar dari PISA dan TIMSS. PPPPTK. 